\title{
SUMBER ZAT GIZI DAN PENILAIAN STATUS GIZI
}

\section{Futri Alifia Rezkiyanti}

\section{Universitas Islam Negeri Alauddin Makassar}

Email : futrialifia@gmail.com

\section{SUMBER ZAT GIZI}

\section{Karbohidrat}

Fungsi utama karbohidrat adalah menyediakan energi bagi tubuh. Karbohidrat merupakan sumber energi utama bagi seluruh penduduk dunia karena relatif terjangkau dan mudah didapatkan. Setiap gram karbohidrat menghasilkan 4 Kkal. Keberadaan karbohidrat di dalam tubuh, sebagian ada pada sirkulasi darah sebagai glukosa, sebagian terdapat pada hati dan jaringan otot sebagai glikogen, dan sebagian lagi sisanya diubah menjadi lemak untuk kemudian disimpan sebagai cadangan energi di dalam jaringan lemak. Kegemukan adalah salah satu akibat dari terlalu banyak mengonsumsi karbohidrat.

Sumber utama karbohidrat di dalam makanan berasari dari tumbuh-tumbuhan (nabati) yaitu bahan makanan pokok seperti beras, jagung, sagu, gandum, kacang-kacangan dan buah-buahan. Sedangkan sumber dari hewani hampir tidak ada, karena karbohidrat dari hewani berbentuk glikogen, terutama dalam daging dan hati, setelah hewan disembelih glikogen mengalami penguraian sehingga di dalam daging, karbohidrat menjadi habis.

\section{Lemak}

Sumber lemak trans yang utama dalam makanan antara lain kentang goreng, donat dan makanan goreng lainnya yang dijual. Sumber lemak trans lainnya meliputi kue kering, kraker, dan makanan panggang lain. Kelompok padi-padian, padi-padian secara alami mengandung sangat sedikit lemak. Namun demikian, makanan olahan yang termasuk dalam kelompok makanan ini, seperti sereal granola, panekuk, donat, kue, kue kering dan pai, banyak mengandung lemak tambahan. Kelompok sayuran dan buah, selain alpukat, kelapa dan zaitun, buah-buahan tidak mengandung lemak. Kelompok susu : produk-produk yang termasuk dalam kelompok susu terbagi menjadi bebas lemak, rendah lemak dan lemak utuh. Kelompok daging dan kacang, bahan nabati dalam kelompok ini (kacang dan polong) bebas kolesterol dan sedikit atau tidak mengandung lemak jenuh. Umumnya, daging yang tidak dibersihkan lebih tinggi kandungan lemaknya daripada daging tanpa lemak dan daging yang berwarna putih lebih rendah lemak daripada daging berwarna gelap (contohnya daging 
ayam). Kerang-kerangan, seperti kepiting, lobster, dan udang, kaya akan kolesterol, tetapi rendah lemak dan rendah lemak jenuh. Setiap gram lemak menghasilkan 9 Kkal.

\section{Protein}

Protein banyak terdapat pada bahan makanan yang berasal dari hewan (protein hewani) seperti daging sapi, ayam, ikan, udang, hati dan telur. Sumber protein hewani ini merniliki kualitas yang baik karena mengandung hampir semua asam amino essensial. Dalam bahan makanan yang berasal dari tumbuhan (protein nabati) seperti kacang tanah, kacang hijau, kacang kedele, hanya sebagian asam amino essensial yang dikandungnya, sehingga perlu kombinasi bahan makanan yang beragam. Setiap gram protein menghasilkan 4 Kkal.

\section{Vitamin}

Vitamin dapat dipilah menjadi 2 kelompok yaitu kelompok yang larut dalam lemak dan yang larut dalam air. Vitamin yang larut dalam lemak terdiri dari vitamin A, D, E dan K. Sedangkan vitamin yang larut dalam air terdiri dari vitamin B kompleks dan vitamin C.

- Manusia memperoleh vitamin A sebagian dari makanan hewani di mana vitamin tersebut sudah terbentuk dan sebagian lagi diperoleh dari karoten yang diperoleh dari sayuran, buah-buahan dan berbagai produk hewani. Makanan yang kaya akan karoten mencakup sayuran, khususnya yangberdaun gelap seperti tomat dan wortel, serta buah buahan terutama yang berwarna kuning seperti mangga.

- Diet yaitu berasal dari jaringan tubuh hewan dimana vitamin D sudah terbentuk sebelumnya, ditemukan di dalam telur, mentega serta ikan yang berlemak. Minyak dari ikan Cod merupakan sumber yang sangat kaya akan vitamin D. Margarin yang berasal dari minyak kelapa sawit menjalani fortifikasi artifisial dengan vitamin D. Susu bubuk yang digunakan untuk bayi dan juga makanan sereal untuk bayi pada banyak keadaan merupakan satu-satunya komponen diet yang mengandung vitamin D bagi golongan usia tersebut.

- Sumber Vitamin E, banyak terdapat dalam bahan makanan. Sumber vitamin E yaitu: minyak gandum/jagung, sayuran, hati, telur, mentega, susu, daging, dan terutama dari tauge. Minyak kelapa dan zaitun mengandung sedikit vitamin E. Kebanyakan makanan berminyak juga mengandung vitamin $\mathrm{E}$. Buah buahan yang mengandung vitamin $\mathrm{E}$ meliputi: alpukat, biji bunga matahari, tomat.

- Sumber utama vitamin K adalah hati, sayuran daun yang berwarna hijau, kacang buncis, kacang polong, kol dan brokoli. Semakin hijau daun-daunan semakin tinggi kandungan 
vitamin K-nya. Bahan makanan lain yang mengandung vitamin $\mathrm{K}$ dalam jumlah yang lebih kecil adalah susu, daging, telur, buah-buahan, dan sayuran lain. Sumber penting vitamin K lain adalah flora bakteri dalam usus halus (jejunum dan ileum).

- Vitamin B1 (Tiamin), Sumber: Nasi, roti, sereal, tepung terigu, makanan laut seperti udang, kepiting atau kerang.

- Vitamin B2 (Riboflavin) : Sumber: Susu, keju, ayam, brokoli, bayam, jamur. Fungsi: Menjaga kesehatan mata dan kulit.

- Vitamin B3 (Niasin) : Sumber: Padi-padian, kacang-kacangan, daging sapi, jamur.

- Vitamin B5 (Pantothenic Acid) : Sumbernya Ayam, ikan sarden, alpukat, semangka.

- Vitamin B6 (Piridoksin) : Sumber: Daging unggas, ikan, sapi, kentang, tomat, pisang, buah yang berwarna ungu dan sayuran hijau.

- Vitamin B7 (Biotin) : Sumber: Daging ikan salmon, telur, susu, sereal, pisang dan kacang tanah.

- Vitamin B9 (Folat) : Sumber: Susu dan produk olahan susu, bit, hati, melon dan sayuran berdaun hijau.

- Vitamin B12 (Kobalamin) : Sumbernya daging sapi, daging ikan, hati, telur, susu, kedelai dan rumput laut.

- Vitamin C, Sumbernya : Sayur-sayuran seperti brokoli, kembang kol, kubis, dan paprika merah,cabai rawit, bayam mentah, sawi, seledri dan mentimum.

\section{Mineral}

Mineral merupakan komponen inorganik yang terdapat dalam tubuh manusia. Sumber paling baik mineral adalah makanan hewani, kecuali magnesium yang lebih banyak terdapat di alam makanan nabati. Hewan memperoleh mineral dari tumbuh tumbuhan dan menumpuknya di jaringan tubuhnya. Disamping itu mineral berasal dari makanan hewani mempunyai ketersediaan biologik lebih tinggi daripada yang berasal dari makanan nabati, Makanan hewani mengandung lebih sedikit bahan pengikat mineral daripada makanan nabati. Menurut jenisnya, mineral dibedakan menjadi 1) Mineral Organik yaitu mineral yang dibutuhkan serta berguna bagi tubuh kita, yang dapat kita peroleh melalui makanan yang kita konsumsi setiap hari seperti nasi, ayam, ikan, telur, sayur-sayuran serta buahbuahan, atau vitamin tambahan.2) Mineral anorganik yaitu mineral yang tidak dibutuhkan serta tidak berguna bagi tubuh kita.Contohnya:Timbal Hitam $(\mathrm{Pb})$, Iron Oxide (Besi Teroksidasi), Mercuri, Arsenik, Magnesium, Aluminium atau bahan-bahan kimia hasil dari resapan tanah dan lain. 


\section{PENILAIAN STATUS GIZI}

Definisi status gizi yaitu keadaan tubuh sebagai akibat konsumsi makanan dan penggunaan zat-zat gizi yang dibedakan menjadi beberapa kategori seperti gizi lebih, gizi baik, dan gizi. Status gizi tersebut dapat dipengaruhi oleh 2 hal pokok yaitu konsumsi makanan dan keadaan kesehatan tubuh atau infeksi. Dalam ilmu gizi baik kondisi gizi lebih maupun gizi kurang atau gizi buruk dimasukkan dalam Malnutrisi (Gizi Salah). Malnutrisi disini merupakan suatu keadaan patologis akibat kekurangan atau kelebihan secara relatif ataupun absolut satu atau lebih zat gizi. Mengenai penilaian status gizi ini terdapat dua metode yaitu penilaian status gizi langsung yang terdiri dari Antropometri, Klinis, Biokimia, Biofisik, dan penilaian status gizi secara tidak langsung yang terdiri dari Survei Konsumsi Makanan, Statistik Vital, Faktor Ekologi.

\section{PENILAIAN STATUS GIZI SECARA LANGSUNG}

\section{Antropometri}

Antropometri diartikan sebagai ukuran tubuh manusia yang digunakan untuk melihat ketidakseimbangan asupan protein dan energi (karbohidrat dan lemak) pada tubuh. Adapun keunggulan dan kelemahan pada antropometri yaitu sebagai berikut.

- Keunggulan antropometri : Alat mudah, dapat dilakukan berulang-ulang \& objektif, siapa saja bisa dilatih mengukur, relatif murah, hasilnya mudah disimpulkan, secara ilmiah diakui kebenarannya, sederhana, aman, bisa sampel besar, tepat, akurat, dapat menggambarkan riwayat gizi masa lalu, bisa untuk skrining \& mengevaluasi status gizi.

- Kelemahan antropometri : tidak sensitif \& spesifik mengukur suatu zat gizi, bisa dipengaruhi faktor diluar gizi misalnya penyakit, bisa terjadi kesalahan pengukuran. Antropometri sebagai indikator status gizi dapat dilakukan dengan mengukur beberapa parameter . Parameter ini terdiri dari :

1. Umur, yaitu bulan penuh untuk anak 0-2 tahun dan tahun penuh $>2$ tahun dihitung dari hari lahir, misalnya bayi usia 6 bulan 10 hari dihitung usia 6 bulan atau anak umur 8 tahun 4 bulan dihitung 8 tahun

2. Berat Badan menggunakan timbangan yang sesuai dan cara yang tepat

3. Tinggi Badan diukur pada posisi lurus dengan cara yang tepat

4. Lingkar Lengan Atas dapat menggunakan pita LILA atau meteran

5. Lingkar Kepala

6. Lingkar dada

7. Jaringan lunak (lemak sub cutan) diukur menggunakan alat khusus. 
Parameter sebagai ukuran tunggal belum bisa digunakan untuk menilai status gizi harus dikombinasikan. Kombinasi beberapa parameter disebut Indeks Antropometri yang terdiri dari : Berat badan menurut umur (BB/U), Tinggi badan menurut umur (TB/U), Berat badan menurut tinggi badan (BB/TB), Lingkar lengan atas menurut umur(LLA/U), Indeks Massa Tubuh (IMT), dll. Banyak sekali sumber yang dapat digunakan untuk menggolongkan status gizi dengan menggunakan indeks antropometri tetapi tetap diperlukan tabel bantu untuk mengetahui parameter normal kemudian baru digolongkan misalnya menggunakan tabel 1.3 dan tabel 1.4 berikut.

Tabel 1.3 Keadaan Gizi Menurut Indeks Antropometri

\begin{tabular}{|l|c|c|c|c|c|}
\hline \multirow{2}{*}{ Status Gizi } & \multicolumn{4}{|c|}{ Ambang batas baku untuk keadaan gizi berdasarkan indeks } \\
\cline { 2 - 6 } & $\mathrm{BB} / \mathrm{U}$ & $\mathrm{TB} / \mathrm{U}$ & $\mathrm{BB} / \mathrm{TB}$ & $\mathrm{LLA} / \mathrm{U}$ & LLA/TB \\
\hline Gizi Baik & $>80 \%$ & $>85 \%$ & $>90 \%$ & $>85 \%$ & $>85 \%$ \\
Gizi Kurang & $61-80 \%$ & $71-85 \%$ & $81-90 \%$ & $71-85 \%$ & $76-85 \%$ \\
Gizi Buruk & $\leq 60 \%$ & $\leq 70 \%$ & $\leq 80 \%$ & $\leq 70 \%$ & $\leq 75 \%$ \\
\hline
\end{tabular}

Tabel 1.4. Klasifikasi Status Gizi Berdasarkan Rujukan Baku WHO-NCHS

\begin{tabular}{|c|c|c|c|}
\hline & $\begin{array}{l}\text { Berat badan menurut } \\
\text { umur }(\mathrm{BB} / \mathrm{U})\end{array}$ & & $\begin{array}{l}\text { Berat badan menurut } \\
\text { tinggi badan }(B B / T B)\end{array}$ \\
\hline $\begin{array}{l}\text { Gizi lebih } \\
\text { Gizi baik } \\
\text { Gizi kurang } \\
\text { Gizi buruk }\end{array}$ & $\begin{array}{l}>2 \text { SD } \\
\leq 2 \text { SD sampai } 2 \text { SD } \\
>-2 \text { SD sampai } \geq-3 \text { SD } \\
<-3 \text { SD }\end{array}$ & $\begin{array}{l}\text { Gemuk } \\
\text { Normal } \\
\text { Kurus } \\
\text { Kurus sekali }\end{array}$ & $\begin{array}{l}>2 S D \\
\geq-2 \text { SD sampai } 2 S D \\
<-2 \text { SD sampai } \geq-3 \text { SD } \\
<-3 \text { SD }\end{array}$ \\
\hline
\end{tabular}

Setiap indeks antropometri memiliki kelebihan dan kelemahan masing-masing misalnya :

- BB/U kelebihannya : Mudah, cepat dimengerti, bisa mengukur status akut \& kronis, sensitif thd perubahan, dapat mendeteksi overweight, sedangkan kelemahannya : dipengaruhi ascites/udema, harus tahu jelas tanggal lahir, sering salah dalam pengukuran.

- TB/U Keuntungannya : alat mudah murah, fleksibel, bisa mengukur gizi masa lampau, sedangkan kelemahan : tinggi badan lambat berubah, posisi harus tepat, umur harus pasti,

- BB/TB Keuntungan : tidak perlu data umur, dpt membedakan proporsi badan gemuk, normal, kurus Kelemahan : Tidak memberikan gambaran tinggi anak menurut seumuran, sulit dilakukan pada balita, alat ukur 2 macam, lebih lama, sering terjadi kesalahan pengukuran. 
- LLA/U keuntungannya : Baik utk menilai Kekurangan Energi Protein (KEP) berat, murah, mudah, kelemahannya : Sulit menentukan ambang batas, sulit menilai pertumbuhan anak 2- 5 thn.

Klasifikasi lain untuk menentukan status gizi bisa menggunakan klasifikasi WHO berikut :

a. Gizi lebih bila BB saat ini : >120\% median BB/u baku WHO-NCHS

b. Gizi baik bila BB saat ini : 80\%-120\% median BB/u baku WHO-NCHS

c. Gizi sedang bila BB saat ini : 70\%-79,9\% median BB/u baku WHO-NCHS

d. Gizi kurangbila BB saat ini : 60\%-69,9\% median BB/u baku WHO-NCHS

e. Gizi buruk bila BB saat ini : $<60 \%$ median BB/u baku WHO-NCHS

Laki-laki dan perempuan sama.

\section{Pemeriksaan Klinis}

Pemeriksaan klinis sebagai salah satu metode penilaian status gizi secara langsung, secara umum terdiri dari dua bagian yaitu 1) riwayat medis / riwayat kesehatan merupakan catatan mengenai perkembangan penyakit, 2) pemeriksaan fisik, yaitu melakukan pemeriksaan fisik dari kepala sampai ujung kaki untuk melihat tanda-tanda dan gejala adanya masalah gizi. Kita mulai dari riwayat medis. Dalam riwayat ini kita mencatat semua kejadian yang berhubungan dengan gejala yang timbul pada penderita beserta faktor-faktor yang mempengaruhinya. Catatan kita haruslah meliputi identitas penderita secara lengkap, riwayat kesehatan saat ini, riwayat kesehatan masa lalu yang berkaitan dengan penyakit saat ini, riwayat kesehatan keluarga yang berkaitan, data lingkungan fisik dan sosial budaya yang berhubungan dengan gizi, data-data tambahan yang diperlukan misalnya adalah riwayat alergi terhadap makanan, jenis diet dan pengobatan yang sedang atau pernah dijalani pasien,dll. Data-data tersebut dapat dikumpulkan melalui wawancara dengan penderita dan keluarga.

\section{Pemeriksaan Fisik}

Pemeriksaan fisik dapat dilakukan melalui teknik inspeksi atau periksa pandang, palpasi atau periksa raba, perkusi atau periksa ketuk dan auskultasi atau pemeriksaan menggunakan stateskop. Semua perubahan pada rambut, kulit, mata,mulut, lidah, gigi, kelenjar tiroid, dll. Menurut Jelliffe dan Jelliffe, tanda-tanda klinis dapat dikelompokkan dalam tiga kelompok besar yaitu :

- Kelompok 1, tanda-tanda yang memang benar berhubungan dengan kurang gizi bisa karena kekurangan salah satu zat gizi atau kelebihan dari yang dibutuhkan tubuh, 
- Kelompok 2, tanda-tanda yang membutuhkan investigasi atau penyelidikan lebih lanjut karena tanda ini mungkin saja merupakan tanda gizi salah atau mungkin disebabkan faktor lain, dan

- Tanda-tanda yang tidak berkaitan dengan gizi salah walaupun hampir mirip, untuk dapat menentukannya diperlukan keahlian khusus. Untuk dapat mengelompokan tanda-tanda yang ada pada pasien, pemeriksa harus mengetahui tanda-tanda dan gejala akibat kekurangan atau kelebihan setaip zat gizi.

Seperti pada metode penilaian status gizi yang lain, pemeriksaan fisik juga memiliki kekurangan dan kelebihan. Kelebihan atau keunggulannya adalah relatif murah, tidak memerlukan tenaga khusus cukup paramaedis terlatih, sederhana, cepat, dan mudah diiterpretasikan, dan peralatan sederhana sedangkan kelemahannya adalah Beberapa gejala klinis tidak mudah dideteksi, kadang tidak spesifik, adanya gejala klinis yang bersifat multipel, gejala dapat terjadi saat permulaan atau tahap akan sembuh dari penyakit, adanya variasi dalam gejala klinis.

\section{Biokimia}

Pemeriksaan biokimia zat gizi terdiri dari 1) penilaian status besi dengan pemeriksaan Haemoglobin $(\mathrm{Hb})$, Hematokrit, Besi serum, Ferritin serum, saturasi transferin, free erytrocites protophoprin, unsaturated iron-binding capacity serum, 2) penilaian status protein dapat dilakukan dengan melakukan pemeriksaan fraksi protein yaitu Albumin, Globulin, dan Fibrinogen, 3) penilaian status vitamin tergantung dari vitamin yang ingin kita ketahui misalnya vitamin A dinilai dengan memeriksa serum retinol, vitamin D dinilai dengan pemeriksaan kalsium serum, vitamin E dengan penilaian serum vitamin E, vitamin C dapat dinilai melalui pemeriksaan perdarahan dan kelainan radiologis yang ditimbulkannya, menilai status riboflavin ( B2) dengan pemeriksaan kandungan riboflavin dalam urine, niasin dinilai dengan pemeriksaan nimetil nicotamin urine. Begitu juga dengan vitamin-vitamin yang lain. Untuk mineral misalnya iodium dinilai dengan memeriksa kadar yodium dalam urine dan kadar hormon TSH ( thyroid stimulating hormone), Zink atau seng dinilai dengan pemeriksaan urine, atau kandungannya dalam plasma, Kalsium dengan memeriksan serum kalsium, begitu juga dengan mineral-mineral yang lain. Hasil pemeriksaan biokima setiap gizi tersebut dibandingkan dengan nilai normalnya masingmasing sehingga bila dibawah nilai normal berarti terdapat kekurangan sebaliknya bila diatas nilai normal bisa jadi karena kelebihan zat gizi tertentu. 


\section{Biofisik}

Penentuan status gizi dengan biofisik adalah melihat kemampuan fungsi jaringan dan perubahan struktur. Tes kemampuan fungsi jaringan meliputi kemampuan kerja dan energi ekspenditure serta adaptasi sikap. Tes perubahan struktur dilihat secara klinis ( misalnya pengerasan kuku, pertumbuhan rambut,dll) atau non klinis (misalnya radiologi). Penilaian secara biofisik dapat dilakukan dengan tiga cara yaitu uji radiologi, tes fungsi fisik (misalnya tes adaptasi pada ruangan gelap), dan sitologi (misalnya pada KEP dengan melihat noda pada epitel dari mukosa oral). Penilaian biofisik ini memerlukan biaya yang besar.

\section{PENILAIAN STATUS GIZI TIDAK LANGSUNG}

\section{Survei Konsumsi Makanan}

Survei ini digunakan dalam menentukan status gizi perorangan atau kelompok. Survei konsumsi makanan dimaksudkan untuk mengetahui kebiasaan makan atau gambaran tingkat kecukupan bahan makanan dan zat gizi pada tingkat kelompok, rumah tangga dan perorangan serta faktor-faktor yang mempengaruhinya. Berdasarkan jenis data yang diperoleh, pengukuran konsumsi makanan menghasilkan dua jenis data yaitu kualitatif (a.1 frekuensi makanan, dietary history, metode telepon, dan daftar makanan) dan data kuantitatif (a.1 metode recall 24 jam, perkiraan makanan, penimbangan makanan, food account, metode inventaris dan pencatatan).

\section{Pengukuran Faktor Ekologi}

Gizi salah merupakan masalah ekolagi sebagai hasil yang saling mempengaruhi dan interaksi beberapa faktor fisik, biologi, dan lingkungan budaya. Faktor ekologi yang berhubungan dengan malnutrisi ada enam kelompok yaitu, keadaan infeksi, konsumsi makanan, pengaruh budaya, sosial ekonomi, produksi pangan, serta kesehatan dan pendidikan.

\section{Statistik Vital}

Salah satu cara untuk mengetahui gambaran keadaan gizi di suatu wilayah adalah dengan cara menganalisi statistik kesehatan. Dengan menggunakan statistik kesehatan, kita dapat melihat indikator tidak langsung pengukuran status gizi masyarakat. Beberapa statistik yang berhubungan dengan keadaan kesehatan dan gizi antara lain angka kesakitan, angka kematian, pelayanan kesehatan, dan penyakit infeksi yang berhubungan dengan gizi. Berikut ini dapat dijelaskan sebagai berikut, angka kematian berdasarkan umur adalah jumlah kematian pada kelompok umur tertentu terhadap jumlah rata-rata penduduk pada kelompok umur tersebut setiap 1.000 penduduk. Manfaat data ini mengetahui tingkat dan 
pola kematian menurut golongan umur dan penyebabnya. Misalnya angka kematian umur 2-37 5 bulan, umur 1-4 tahun, umur 13 - 24 bulan. Angka kesakitan dan kematian akibat penyebab tertentu, angka penyebab kematian pada umur 1-4 tahun merupakan informasi penting untuk menggambarkan keadaan gizi di suatu masyarakat. Kita lanjutkan dengan statistik layanan kesehatan misalnya Posyandu, Puskesmas, dan Rumah Sakit, berikutnya Infeksi yang Relevan dengan Keadaan Gizi. Statistik vital ini hanya berupa data pendukung, masih harus dikaji faktor-faktor lain yang berhubungan sehingga status gizi dapat ditentukan dengan akurat. Seperti metode yang lain statistik vital mempunyai kelemahan antara lain : data tidak akurat, adanya kesulitan dalam mengumpulkan data, dipengaruhi oleh kemampuan menginterpretasikan data secara tepat. 


\section{DAFTAR PUSTAKA}

1. Alam, S., \& Kartini, T. A. (2020). Islamic Parenting” Pola Asuh Anak: Tinjauan Perspektif Gizi Masyarakat”.

2. Mardalena, I., \& Suryani, E. Ilmu Gizi. Modul Bahan Ajar Cetak Keperawatan, 3-4. Kementrian Kesehatan Republik Indonesia.

3. Syafrizar., \& Welis, W. (2008). Ilmu Gizi. Wineka Media, 2-3. 